\title{
Overexpression of class I major histocompatibility complex accompanies insulitis in the non-obese diabetic mouse and is prevented by anti-interferon- $\gamma$ antibody
}

\author{
T. W. H. Kay, I. L. Campbell, L. Oxbrow and L.C.Harrison \\ Walter and Eliza Hall Institute of Medical Research, Royal Melbourne Hospital, Victoria, Australia
}

\begin{abstract}
Summary. Overexpression of class I major histocompatibility complex (MHC) proteins on pancreatic islet cells is a characteristic of autoimmune Type 1 (insulin-dependent) diabetes mellitus in humans and in animal models. Studies of post-mortem pancreases from humans with Type 1 diabetes suggest that overexpression of class I MHC proteins may precede mononuclear cell infiltration of the islets (insulitis). Pancreatic histology from the earliest stages of human Type 1 diabetes is rarely available. We have used the non-obese diabetic mouse, given cyclophosphamide to accelerate Betacell destruction, to investigate the temporal relationship between the overexpression of class I MHC protein and mRNA and other pathological changes associated with Beta-cell destruction. Prior to cyclophosphamide, immunoperoxidase staining showed that expression of class I MHC proteins was greater on islet cells and infiltrating inflammatory cells of the non-obese diabetic mouse than on islet cells of other mouse strains, whereas staining on exocrine cells was similar. On day three after cyclophosphamide administration, when insulitis had regressed, islet class I MHC protein expression had diminished. A dramatic increase in class I MHC protein expression occurred between days seven and nine, concomitant with reinfiltration of the islets by mononuclear cells; overexpression was seen both on islet cells and on surround-
\end{abstract}

ing exocrine cells, but only in the presence of mononuclear cell infiltration. By day 21, class I MHC protein overexpression was again confined to the islets, the exocrine pancreas being free of infiltration. Class I mRNA also increased dramatically by day eight but had virtually returned to normal by day 12. Overexpression of class I MHC protein following cyclophosphamide was prevented by administration of antiinterferon- $\gamma$ antibody. Expression of class II MHC proteins was not detected on pancreatic cells following cyclophosphamide but was present on infiltrating mononuclear cells. These findings demonstrate a close association between class I MHC protein and mRNA overexpression and insulitis in non-obese diabetic mice given cyclophosphamide. They are consistent with the view that class I MHC overexpression is effected by cytokines secreted by activated immunoinflammatory cells. Class I MHC overexpression should enhance targeting of cytotoxic $\mathrm{T}$ cells to Beta cells bearing autoantigen.

Key words: Type 1 (insulin-dependent) diabetes mellitus, non-obese diabetic (NOD) mouse, pancreatic islets, class I major histocompatibility complex (class I MHC), anti-interferon- $\gamma$ antibodies.
The class I major histocompatability complex (MHC) genes encode cell surface glycoproteins that are involved in recognition of cellular peptide antigens by cytotoxic T cells $[1,2]$. Proposed functions of class I MHC proteins outside the immune system are controversial, especially as mice which have been genetically manipulated not to express class I MHC gene products, although lacking cytotoxic $T$ cells, are otherwise developmentally normal $[3,4]$. In humans who die soon after the diagnosis of Type 1 (insulin-dependent) diabetes mellitus, overexpression of class I MHC proteins has been observed on all cell types within pancreatic islets that contain residual insulin [5-7]. Whether class I MHC overexpression is secondary to the presence of immuno-inflammatory cells or whether both are secondary to another event, e. g. virus infection, and its functional relevence for Beta-cell destruction, are important questions that are difficult to resolve in humans because the pathology is invariably far-advanced at clinical presentation and pancreatic tissue is rarely available. However, class I MHC overexpression is also present in the animal models of Type 1 diabetes, the Bio-Breeding (BB) rat [8-10], the multi low-dose streptozotocin (MLDS) mouse $[11,12]$ and the non-obese diabetic (NOD) mouse, and these provide the opportunity to relate the expression of class I MHC to other pathological changes associated with Beta-cell destruction. 

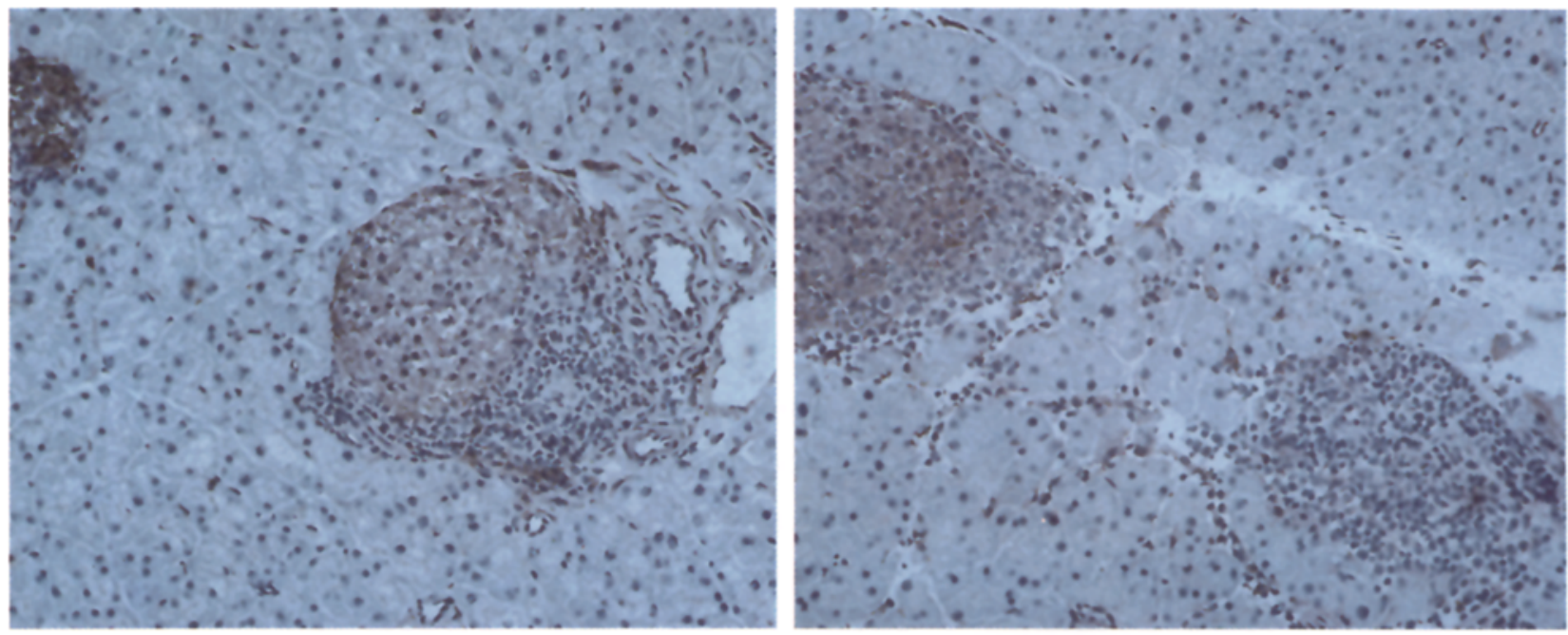

Insulin

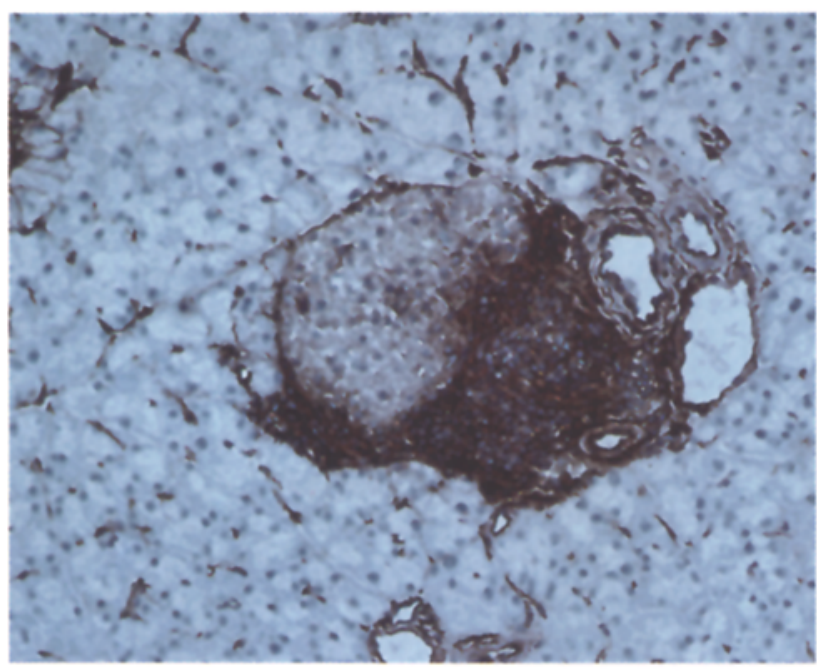

Day 0

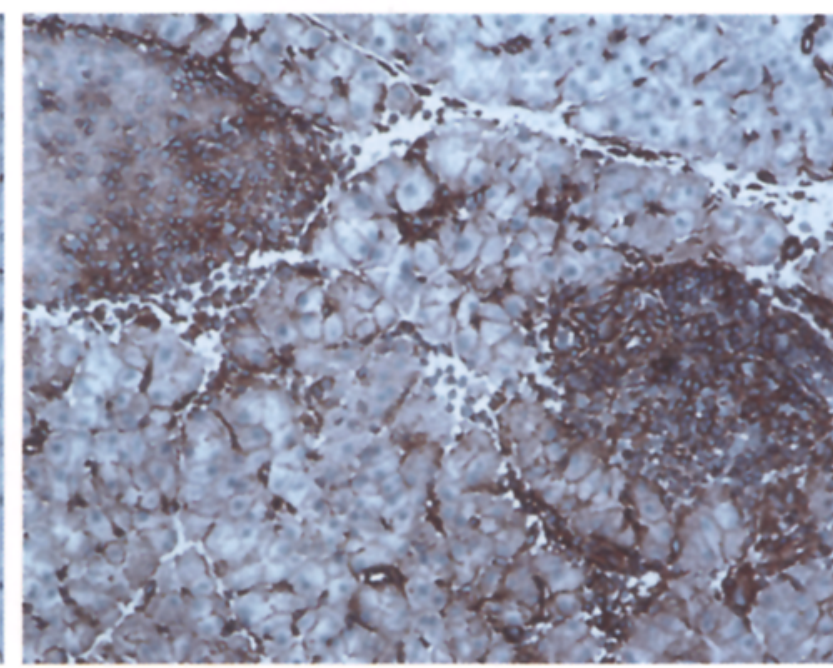

Day 7

Class I

Fig. 1. Immunoperoxidase staining for insulin (top) and class I MHC protein (bottom) in the pancreas of NOD mice before (left) and 7 days (right) after the administration of cyciophosphamide $300 \mathrm{mg} / \mathrm{kg}(\times 200)$

Administration of cyclophosphamide to NOD mice results in predictable acceleration of Beta-cell destruction within 7 to 14 days and hyperglycaemia in $60 \%$ of female mice $[13,14]$. Both cyclophosphamide-accelerated and spontaneous diabetes in NOD mice can be inhibited by monoclonal antibodies to T lymphocyte subsets [15-17] or by the anti-macrophage agent silica $[18,19]$, and diabetes can be transferred to normoglycaemic mice by splenic $T$ cells [20-22]. In previous studies [23] we have shown that $T$ cells disappear from the NOD mouse pancreas 2 to 3 days following cyclophosphamide administration then reappear in much greater numbers one week later. At the time of reinfiltration the majority of the $\mathrm{T}$ cells are $\mathrm{CD} 4$ positive, whereas after 10 days, when hyperglycaemia develops, CD8 cells predominate. The reinfiltrating $T$ cells express activation markers and secrete cytokines ex vivo [23]. Cyclophosphamide therefore compresses events that occur spontaneously at variable rates over several months in individual NOD mice and enables analysis of the sequence of pathological changes, including class I MHC overexpression, that precede the development of hyperglycaemia.

\section{Materials and methods}

\section{Mice}

NOD mice were from the colony at the Walter and Eliza Hall Institute obtained in 1984 from Dr. H. Asamoto (Kyoto, Japan). This colony has a low incidence of spontaneous diabetes [24] although all mice develop insulitis and cyclophosphamide induces overt diabetes in $60 \%$ of females [14]. Cyclophosphamide ( $300 \mathrm{mg} / \mathrm{kg}$, Farmitalia, Victoria, Australia) was given i. p. in $154 \mathrm{mmol} / \mathrm{l} \mathrm{NaCl}$ to female mice aged 80-110 days. Following cyclophosphamide or $154 \mathrm{mmol} / \mathrm{l}$ $\mathrm{NaCl}$ alone four mice from each group were killed for immunohistology on days 3, 7, 8, 10 and 21. In addition, on day 12 after cyclophosphamide, four hyperglycaemic and four normoglycaemic mice were killed for immunohistology. Cyclophosphamide or $154 \mathrm{mmol} / \mathrm{l} \mathrm{NaCl}$ was also given to female CBA mice of the same age. 
$H$ \& $E$

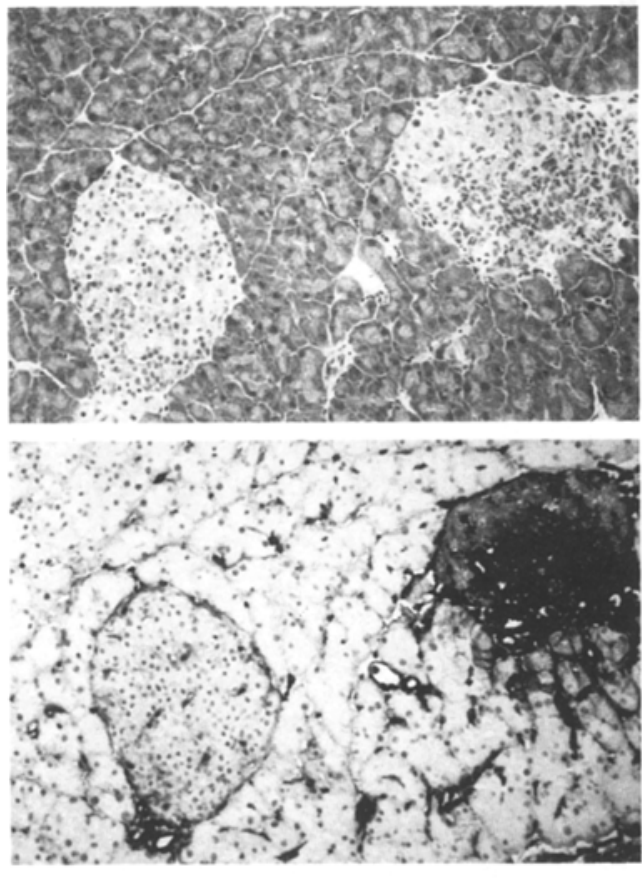

Class 1
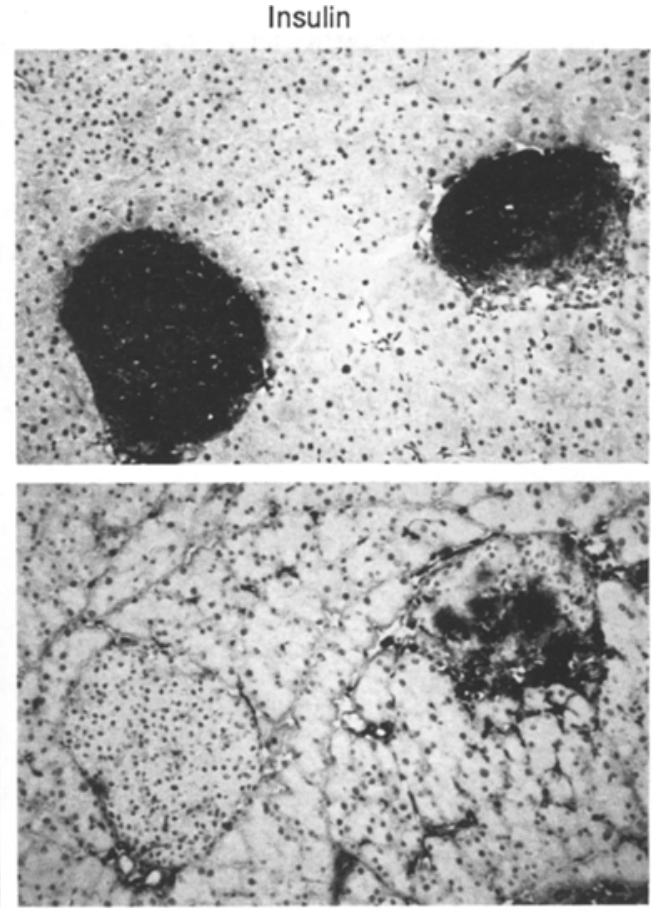

Class ॥
Fig. 2. Haematoxylin and eosin $(\mathrm{H} \& \mathrm{E})$ and immunoperoxidase staining for insulin, class I MHC protein and class II MHC protein in the pancreas of an NOD mouse 7 days after the administration of cyclophosphamide $300 \mathrm{mg} / \mathrm{kg}$. The islet in the lower left corner shows no insulitis and no class I MHC protein overexpression whereas the islet in the top right corner shows insulitis and class I MHC protein overexpression $(\times 200)$

\section{Immunoperoxidase staining}

MHC proteins were detected in the pancreases of the mice by indirect immunoperoxidase as previously described [11] using monoclonal antibody 34-1-2S directed against the $\mathrm{H}-2 \mathrm{~K}^{d} \mathrm{D}^{\mathrm{d}}$ protein [26] and 10-2.16 against monomorphic specificities on the $\mathrm{I}-\mathrm{A}^{\mathrm{k}}$ protein [27]. Briefly, acetone-fixed $5 \mu \mathrm{m}$ frozen sections of pancreases were incubated with the appropriate monoclonal antibody for $30 \mathrm{~min}$ at room temperature, washed and then incubated with peroxidase-conjugated rabbit anti-mouse immunoglobulin (Dakopatts, Copenhagen, Denmark), prior to colour development with 3'5'-diaminobenzidine and hydrogen peroxidase. Insulin was detected similarly but with guinea-pig anti-insulin serum (Miles-Yeda, Rehovot, Israel) and peroxidase-conjugated anti-guinea-pig immunoglobulin (Dakopatts).

\section{$R N A$ extraction and Northern blotting}

Following cyclophosphamide or $154 \mathrm{mmol} / \mathrm{l} \mathrm{NaCl}$, three mice from each group were killed for isolation of total pancreas RNA on days $3,7,8$ and 10 , and on day 12 (three hyperglycaemic and three normoglycaemic mice). Total RNA was extracted from each pancreas by homogenization in guanidinium isothiocyanate [23], replicates pooled and poly-A mRNA purified on an oligo-dT cellulose column. Poly-A mRNA, $5 \mu \mathrm{g}$ per sample measured by absorbance at $260 / 280 \mathrm{nmol} / \mathrm{l}$, was fractionated in $1 \%$ agarose/formaldehyde gels and transferred to Biotrace RP nylon membranes (Gelman Sciences Inc., Ann Arbor, Mich., USA). The filters were probed with a mouse class I MHC cDNA labelled by nick translation with $\left[\alpha_{-}{ }^{32} \mathrm{P}\right]$ ATP (Amersham, Amersham, Bucks., UK). Subsequently, the filters were reprobed with similarly labelled cDNAs for mouse interferon- $\gamma$ (IFN- $\gamma$ ), interleukin 3 (IL-3) and granulocyte-macrophage colony stimulating factor (GM-CSF). cDNA probes were obtained from Dr. N.M. Gough, Walter and Eliza Hall Institute.

\section{Administration of anti-interferon- $\gamma($ IFN- $\gamma)$ antibody}

Monoclonal antibody to IFN- $\gamma$ (RA-642; hybridoma cells obtained from the American Type Culture Collection, Rockville, Md., USA) was purified from $\mathrm{CBA}-\mathrm{Nu} / \mathrm{Nu}$ mouse ascites by ammonium sulphate precipitation and stored at a concentration of $1 \mathrm{mg} / \mathrm{ml}$ in phosphate-buffered saline. Female NOD mice aged $80-110$ days in groups of four were randomly allocated to receive either rat immunoglobulin (Sigma Chemical Co., St Louis, Mo., USA) or RA-642 in a dose of $0.5 \mathrm{ml}$ i. p. on days 1,3 and 6 relative to injection of cyclophosphamide on day 0 .

\section{Results}

\section{Immunoperoxidase staining for MHC class I proteins}

Before the injection of cyclophosphamide, NOD mouse islets exhibited class I MHC protein overexpression relative both to the islets of normal adult CBA mice and to the surrounding exocrine tissue. Both the islet cells and the infiltrating lymphoid cells were strongly stained and there was no evidence of greater expression on Beta cells than on other islet cell types (Fig. 1). Three days after cyclophosphamide administration, insulitis had disappeared and class I MHC protein expression on islet cells had diminished (not shown). Seven to 10 days after cyclophosphamide, there was a dramatic increase in class I MHC protein expression first on islet cells and then also on exocrine cells, coincident with the increase in inflammatory cell infiltrate. Class I MHC protein overexpression began focally in relation to the infiltrate and then appeared to expand so that, by 7 to 8 days after cyclophosphamide, insulitis involved most islets and class I MHC protein 
$\begin{array}{llllllll}0 & 3 & 7 & 8 & 10 & 12 & 12 & 21\end{array}$

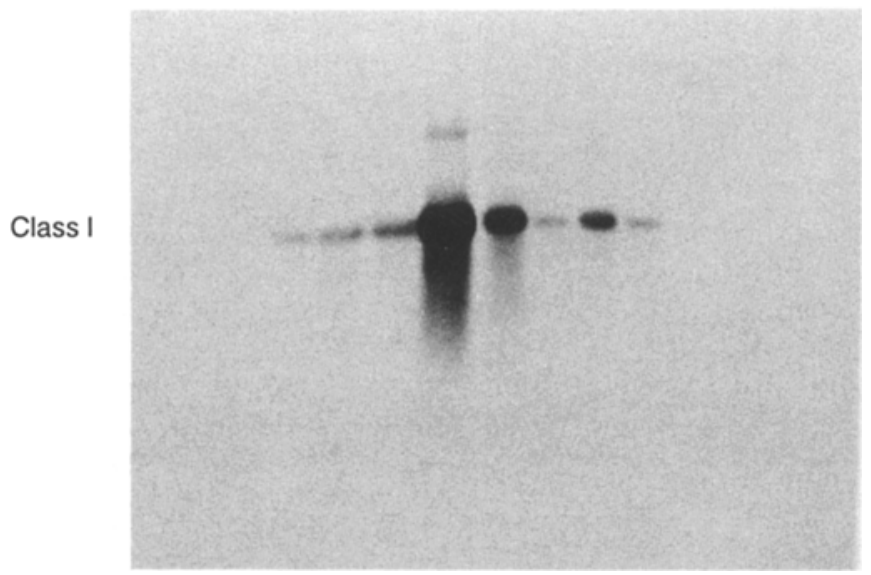

Fig. 3. Northern hybridization with a probe for class I MHC RNA of $5 \mu \mathrm{g}$ poly-A mRNA from NOD mouse pancreas before and after cyclophosphamide. Days after cyclophosphamide are indicated above the lanes. Pancreatic mRNA from three mice was pooled for each time point. The two lanes labelled day 12 are non-diabetic mice and diabetic mice, respectively, at this time point

overexpression was present throughout the pancreas (Fig.1). Class I MHC protein overexpression was not apparent on islet cells in the absence of inflammatory cells in the islet (Fig. 2), or on exocrine cells unless there was a nearby islet with class I MHC protein overexpression and insulitis. Class IMHC protein overexpression was present throughout the pancreas for approximately one week, with more than $50 \%$ of the animals becoming hyperglycaemic between days 11 and 14. By day 21 class I MHC protein expression on the exocrine tissue had returned to control levels and was considerably lower than on islet cells. No change in class I MHC protein expression was seen on NOD kidney cells or on CBA mouse pancreas following cyclophosphamide administration (not shown).

\section{Inflammatory changes in the exocrine pancreas}

Class I MHC protein overexpression on exocrine cells was accompanied by an inflammatory cell infiltrate and oedema throughout the pancreas. Immunoperoxidase staining with monoclonal antibodies demonstrated both $T$ cells and macrophages (not shown). The time course of these changes was the same as for class I MHC protein overexpression by exocrine cells and they had resolved by day 21 .

\section{Class IMHC mRNA expression}

Northern blot analysis using a cDNA probe for class I MHC mRNA showed a similar pattern to immunoperoxidase staining for class I MHC protein, with a dramatic increase by day 8 after cyclophosphamide, a fall by day 12 and a return to control levels or less by day 21 (Fig.3). Northern blot analysis for mRNA specific for the cytokines IFN- $\gamma$, IL-3 and GM-CSF was also performed using $\alpha_{-}{ }^{32} \mathrm{P}$-[ATP]-labelled cDNA probes but transcripts were not detected.
Immunoperoxidase staining for MHC class II proteins

Class II MHC protein staining was present on numerous cells in the inflammatory islet infiltrate as well as on cells scattered throughout the exocrine pancreas especially along septa dividing lobules and around vessels. Extraislet class II MHC protein staining was unchanged 3 days after cyclophosphamide but after 7 days there was an increase in the number of class II MHC protein strongly positive cells both around the islet and within the exocrine pancreas (Fig. 2). These cells appeared to be infiltrating inflammatory cells and included many macrophages. There was no evidence for induction of class II MHC protein on exocrine or endocrine cells following cyclophosphamide.

\section{Administration of anti-IFN-Yantibody}

We have previously shown that administration of antiIFN- $\gamma$ antibody to NOD mice decreases the degree of insulitis and prevents the development of hyperglycaemia 15 days after cyclophosphamide administration [28]. In the present study, NOD mice given either anti-IFN- $\gamma$ antibody or control rat immunoglobulin were killed on day 8 after cyclophosphamide and their pancreases examined for class I MHC protein expression by immunohistochemistry. In contrast to mice given cyclophosphamide alone, mice also given anti-IFN- $\gamma$ antibody had markedly reduced expression of class I MHC proteins on islet and exocrine cells (Fig.4).

\section{Discussion}

Class I MHC proteins are overexpressed throughout the NOD mouse pancreas between 7 and 14 days after cyclophosphamide administration, not only on islet endocrine cells but also on exocrine cells. The time course for class I MHC protein overexpression coincides with the reappearance of islet infiltration and exocrine pancreatitis. Class I MHC mRNA and protein levels follow a similar course but mRNA appears to decrease more rapidly indicating that the class I protein is relatively more stable.

The stimulus for class I MHC overexpression in the NOD mouse pancreas is uncertain. Increased expression of class I MHC mRNA occurs primarily at the level of transcription $[29,30]$; sequences responsible for induction by interferons $[29,30]$, tumour necrosis factor [31] and viruses [32] have been defined and several of the corresponding transactivating proteins have been identified. In the normal Beta cell class I MHC proteins are expressed at a low level but are upregulated by cytokines including IFN- $\gamma[25]$ and tumour necrosis factor $[33,34]$ or by viruses such as reovirus that infect islet cells [35].

In patients who have died soon after the development of Type 1 diabetes, class I MHC protein overexpression on Beta, Alpha and Delta cells has been a remarkably consistent finding [5-7] and has been postulated to precede insulitis because it is present in some islets in the absence of infiltrating inflammatory cells. These islets also 


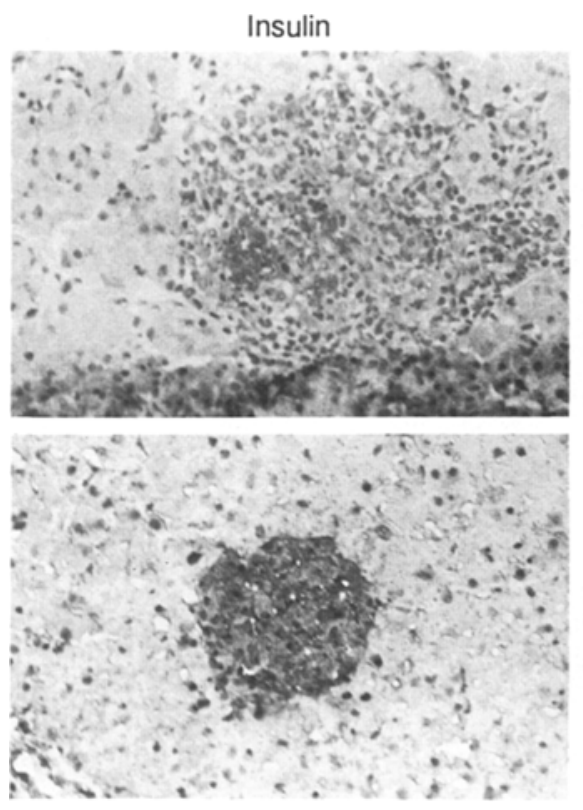

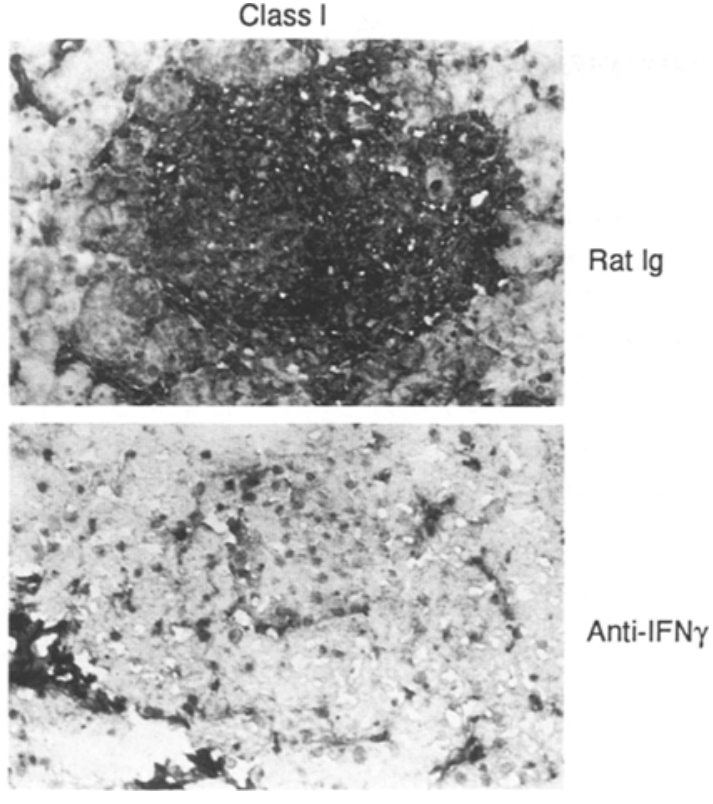

Fig.4. Immunoperoxidase staining for insulin and class I MHC protein in the pancreas of an NOD mouse 8 days after the mouse was given cyclophosphamide with either control rat immunoglobulin (above) or anti-interferon- $\gamma$ $($ IFN- $\gamma)$ antibody (below) $(\times 200)$ contain IFN- $\alpha$ [6]. One explanation for these findings is that IFN- $\alpha$ and class I MHC overexpression both reflect infection with an unidentified virus and that the cellular infiltrate is a secondary response.

There is, however, no direct prospective evidence that class I MHC overexpression precedes insulitis in humans because tissue is not available at the time the disease process commences, before diabetes is clinically apparent. The cyclophosphamide-accelerated NOD mouse model provides the opportunity to study the pancreas before and during the disease process, which is relatively synchronous between animals. The present results indicate that class I MHC overexpression in the NOD mouse pancreas accompanies insulitis and is therefore likely to be secondary to cytokine secretion from activated mononuclear cells. This same relationship between class I MHC overexpression and insulittis was also shown recently in a transfer model of diabetes in which splenocytes from diabetic NOD mice were injected i.v. into irradiated disease-free, male NOD mice [36]. Overexpression of class I MHC was only associated with intra-islet infiltration and was not seen in non-infiltrated islets.

Although class I overexpression may not be required for initiation of insulitis it may, however, be required for amplification and full development of the pathology. A role for cytokines in stimulating class I MHC overexpression is further supported in this study by the effect of antiIFN- $\gamma$ antibodies to prevent class I MHC overexpression and insulitis. Further experiments are planned in which anti-IFN- $\gamma$ will be withheld until insulitis has developed, to clarify whether class I MHC overexpression depends directly on IFN- $\gamma$ secretion. In the multi-low dose streptozotocin model of autoimmune diabetes anti-IFN- $\gamma$ antibodies also prevent class I MHC overexpression [12]. Type A retrovirus particles have been observed by electronmicroscopy in NOD mouse Beta cells following cyclophosphamide [37] and Type C retrovirus has been amplified by the polymerase chain reaction from NOD mouse islets immediately after cyclophosphamide (L.C.Harrison, unpublished results). However, retrovirus expression is unlikely to be the direct stimulus for class I MHC overexpression as the phenomenon is delayed for one week after cyclophosphamide and retrovirus expression in islets would not explain why exocrine cells, not observed to express retrovirus particles, also overexpress class I MHC.

In addition to asking what stimulates class I MHC overexpression we should question how the response is switched off. Class I MHC mRNA expression begins to decrease before the onset of hyperglycaemia when the stimulus to class I MHC expression is still likely to be present. Similar kinetics were noted in previous studies of class I MHC mRNA regulation [38]. Class I MHC mRNA level and transcription rate measured by nuclear run-off assay peaked 2 to $4 \mathrm{~h}$ after exposure to IFN- $\alpha$ and fell by $10-13 \mathrm{~h}$ despite the continuing presence of IFN- $\alpha$. Similarly, in RINm5F insulinoma cells, rat IFN- $\gamma$ induced expression of class I mRNA which peaked at $24 \mathrm{~h}$ and then fell [39]. As Korber et al. [30] have pointed out, there are striking similarities between the regulatory regions and transactivating proteins for class I MHC genes and the inducible response element of the IFN- $\beta$ gene which also undergoes repression following induction by Sendai virus. Recent evidence shows that both transcriptional repression and mRNA destabilization are involved in decreasing IFN- $\beta$ mRNA levels [40]. The transcriptional effect can be blocked by cycloheximide suggesting that there is synthesis of a virus-inducible repressor protein which may bind to the same DNA site. Similar mechanisms operating in the class I MHC and other genes may help explain at a molecular level the time course of immunopathological changes observed in the NOD mouse islets after cyclophosphamide.

Class I MHC proteins bind peptide antigens and, together, are recognised on target cells by cytotoxic T cells. Targetting of Beta cells by cytotoxic T cells in Type 1 diabetes should therefore be increased by overex- 
pression of class I MHC protein. A close association between class I MHC expression and recognition by cytotoxic $\mathrm{T}$ cells has been most clearly demonstrated in several models of virus-induced carcinogenesis in which tumourigenicity correlates inversely with class I MHC expression and cytotoxic $\mathrm{T}$ cell response [41]. Experimental elevation of class I MHC protein expression by transfection of class I genes into class I-deficient, virally transformed cells or by treatment of the cells with IFN- $\gamma$ increases the cytotoxic $\mathrm{T}$ cell response and decreases tumourigenicity [41]. Consistent with this, class I MHC expression following cyclophosphamide is maximal when CD8 T cell infiltration is maximal and Beta-cell destruction is occurring [23]. Furthermore, CD8 T cells isolated from NOD mouse islets have been shown to be specifically cytotoxic for NOD islets in vitro [42]. These data link the findings of increased expression of islet class I MHC proteins following exposure of islets to cytokines or viruses in vitro and those in the Type 1 diabetic pancreas, and support a role for class I MHC overexpression in promoting Beta-cell destruction by cytotoxic $\mathrm{T}$ cells.

Acknowledgements. TWHK was a recipient of a Post-Graduate Medical Research Scholarship of the Anti-Cancer Council of Victoria. ILC is a Senior Research Officer and LCH a Senior Principal Research Fellow of the National Health and Medical Research Council of Australia. This work was supported by a Research Project Grant from the Juvenile Diabetes Foundation International. The authors thank Ms. J. Lygnos for secretarial assistance.

\section{References}

1. Hood L, Steinmetz M, Malissen B (1983) Genes of the major histocompatibility complex of the mouse. Ann Rev Immunol 1: $529-568$

2. Zinkernagel RM, Doherty PC (1980) MHC-restricted cytotoxic $T$ cells: studies on the biological role of polymorphic major transplantation antigens determining T-cell restriction-specificity, function and responsiveness. Adv Immunol 27: 51-77

3. Ziilstra M, Bix M, Simister NE, Loring JM, Raulet DH, Jaenisch $\mathrm{R}$ (1990) B2-microglobulin deficient mice lack CD4-8 + cytolytic lymphocytes. Nature 344: 742-747

4. Koller BH, Marrack P, Kappler JW, Smithies O (1990) Normal development of mice deficient in $\beta 2 \mathrm{M}$, MHC class I proteins and CD8 + T cells. Science 248: 1227-1230

5. Foulis AK, Farquharson MA, Hardman R (1987) Aberrant expression of Class II major histocompatibility complex molecules by $B$ cells and hyperexpression of Class I major histocompatibility complex molecules by insulin-containing islets in Type 1 (insulin-dependent) diabetes mellitus. Diabetologia 30: 333-343

6. Foulis AK, Farquharson MA, Meager A (1987) Immunoreactive alpha-interferon in insulin-secreting beta cells in type 1 diabetes mellitus. Lancet II: 1423-1427

7. Bottazzo GF, Dean BM, McNally JM, Mackay EI, Swift PGF, Gamble DR (1985) In situ characterization of autoimmune phenomena and expression of HLA molecules in the pancreas in diabetic insulitis. N Engl J Med 313: 353-360

8. Kolb H, Hannenberg H, Kantwerk-Funke G, Kiesel U, KolbBachofen V (1988) Natural course of prediabetic islet inflammation in the BB rat. Quantitative analysis. Diab Res Clin Prac 5: S527

9. Baird JD, Walker R, Bone AJ, Cooke A (1988) Role of aberrant expression of class II MHC molecules in pancreatic islet $\beta$ cells in the development of insulin-dependent diabetes mellitus. Diab Res Clin Prac 5: \$134
10. Ono SJ, Issa-Chergui B, Colle E, Guttmann RD, Seemayer TA Fuks A (1988) IDDM in BB rats. Enhanced MHC class I heavychain gene expression in pancreatic islets. Diabetes 37:1411-1418

11. Campbell IL, Oxbrow L, Koulmanda M, Harrison LC (1988) IFN-gamma induces islet cell MHC antigens and enhances autoimmune, streptozotocin-induced diabetes in the mouse. J Immunol 140: 1111-1116

12. Cockfield SM, Ramassar V, Urmson J, Halloran PF (1989) Multiple low dose streptozotocin induces systemic MHC expression in mice by triggering $\mathrm{T}$ cells to release IFN- $\gamma$. J Immunol 142: $1120-1128$

13. Harada M, Makino S (1984) Promotion of spontaneous diabetes in non-obese diabetes-prone mice by cyclophosphamide. Diabetologia 27: 604-606

14. Charlton B, Bacelj A, Slattery RM, Mandel TE (1989) Cyclophosphamide induced diabetes in NOD/WEHI mice. Evidence for suppressor activity in a spontaneous autoimmune disease. Diabetes 38: 441-447

15. Koike T, Itoh Y, Ishii T et al. (1987) Preventive effect of monoclonal anti-L3T4 antibody on development of diabetes in NOD mice. Diabetes 36: 539-541

16. Charlton B, Mandel TE (1988) Progression from insulitis to beta cell destruction in NOD mouse requires $\mathrm{L} 3 \mathrm{~T} 4+\mathrm{T}$ lymphocytes. Diabetes 37: 1108-1112

17. Shizuru JA, Taylor-Edwards C, Banks BA, Gregory AK, Fathman CG (1988) Immunotherapy of the nonobese diabetic mouse. Treatment with an antibody to T-helper lymphocytes. Science 240: 659-662

18. Charlton B, Bacelj A, Mandel TE (1988) Administration of silica particles or anti-Lyt 2 antibody prevents beta-cell destruction in NOD mice given cyclophosphamide. Diabetes 37: 930-935

19. Lee K-U, Amano K, Yoon J-W (1988) Evidence for initial involvement of macrophage in development of insulitis in NOD mice. Diabetes 37: 989-991

20. Bendelac A, Carnaud C, Boitard C, Bach JF (1987) Syngeneic transfer of autoimmune diabetes from diabetic NOD mice to healthy neonates. Requirement for both $\mathrm{L} 3 \mathrm{~T} 4^{+}$and $\mathrm{Lyt}-2^{+}$ T cells. J Exp Med 166: 823-832

21. Miller BJ, Appel MC, O'Neil JJ, Wicker LS (1988) Both the Lyt-2 + and L3T4 + T cell subsets are required for the transfer of diabetes in non-obese diabetic mice. J Immunol 140: 52-58

22. Yasunami R, Bach J-F (1988) Anti-suppressor effect of cyclophosphamide on the development of spontaneous diabetes in NOD mice. Eur J Immunol 18: 481-484

23. Kay TWH, Campbell IL, Harrison LC (1991) Characterization of pancreatic $\mathrm{T}$ lymphocytes associated with beta cell destruction in the non-obese diabetic (NOD) mouse. J Autoimmunity 4: 263-276

24. Baxter AG, Adams MA, Mandel TE (1989) Comparison of highand low-diabetes-incidence NOD mouse strains. Diabetes 38 : $1296-1300$

25. Campbell IL Wong GHW, Schrader JW, Harrison LC (1985) Interferon-gamma enhances the expression of the major histocompatibility class I antigens on mouse pancreatic beta cells. Diabetes 34: 1205-1209

26. Ozato K, Mayer NM, Sachs DH (1982) Monoclonal antibodies to mouse major histocompatibility complex antigens. Transplantation $34: 113-120$

27. Oi VT, Jones PP, Goding JW, Herzenberg LA (1978) Properties of monoclonal antibodies to mouse Ig allotypes H-2 and Ia antigens. Curr Top Microbiol Immunol 81: 115-120

28. Campbell IL, Kay TWH, Oxbrow L, Harrison LC (1991) Essential role for interferon- $\gamma$ and interleukin- 6 in autoimmune insulin-dependent diabetes in NOD/WEHI mice. J Clin Invest 87:739-742

29. Friedman RL, Stark GR (1985) $\alpha$-Interferon-induced transcription of HLA and metallothionen genes containing homologous upstream sequences. Nature 314: 637-639

30. Korber B, Mermod N, Hood L, Stroynowski I (1988) Regulation of gene expression by interferons: control of $\mathrm{H}-2$ promoter responses. Science 239: 1302-1306 
31. Israel A, Le Bail O. Hatat D et al. (1989) TNF stimulates expression of mouse MHC class I genes by inducing an NF KB-like enhancer binding activity which displaces constitutive factors. EMBO 8: 3793-3800

32. Katoh S, Ozawa K, Kondoh S et al. (1990) Identification of sequences responsible for positive and negative regulation by $\mathrm{E} 1 \mathrm{~A}$ in the promoter of $\mathrm{H}-2 \mathrm{~K}^{\mathrm{bml}}$ class I MHC gene. EMBO 9: 127-135

33. Pujol-Borrell R, Todd I, Doshi M et al. (1987) HLA class II induction in human islet cells by interferon-gamma plus tumour necrosis factor or lymphotoxin. Nature 326:304-306

34. Campbell IL, Oxbrow L, West J, Harrison LC (1988) Regulation of MHC protein expression in pancreatic $\beta$-cells by interferon- $\gamma$ and tumour necrosis factor- $\alpha$. Mol Endocrinol 2: 101-107

35. Campbell IL, Harrison LC, Ashcroft RG, Jack I (1988) Reovirus infection enhances expression of class I MHC proteins on human $\beta$-cell and rat RINm5F cell. Diabetes 37: 362-365

36. O'Reilly LA, Hutchings PA, Crocker PR et al. (1991) Characterization of pancreatic islet cell infiltrates in NOD mice: effect of cell transfer and transgene expression. Eur J Immunol 21: $1171-1180$

37. Suenaga K, Yoon J-W (1986) Association of $\beta$ cell-specific expression of endogenous retrovirus with development of insulitis and diabetes in NOD mouse. Diabetes 37: 1722-1726

38. Rosa F, Le Bouteiller PP, Abadie A et al. (1983) HLA class I genes integrated into murine cells are inducible by interferon. Eur J Immunol 13: 495-499
39. Ono SJ, Colle E, Guttmann RD, Fuks A (1989) Interferon- $\gamma$ induces transcription and differential expression of MHC genes in rat insulinoma cell line RIN m5F. Diabetes 38: 911-916

40. Whittemore L-A, Maniatis T (1990) Postinduction turnoff of beta-interferon gene expression. Mol Cell Biol 64: 1329-1337

41. Tanaka K, Yoshioka T, Bieberich C, Jay G (1988) Role of the major histocompatibility complex class I antigens in tumour growth and metastasis. Annu Rev Immunol 6: 359-380

42. Nagata M, Yokono K, Hayakawa M et al. (1989) Destruction of pancreatic islet cells by cytotoxic T lymphocytes in nonobese diabetic mice. J Immunol 143: 1155-1162

Received: 5 March 1991

and in revised form: 10 July 1991

Prof. L. C. Harrison

Burnet Clinical Research Unit

Walter and Eliza Hall Institute of Medical Research

PO Royal Melbourne Hospital

Victoria 3050

Australia 